\title{
Development of Underwater Laser Scanner with Efficient and Flexible Installation for Unmanned Underwater Vehicle
}

\author{
Yeongjun Lee*, Yoongeon Lee*, Junbo Chae*, Hyun-Taek Choi ${ }^{*}$ and Tae-Kyeong Yeu ${ }^{*}$ \\ "Marine ICT Research Division, KIRISO, Daejeon, Korea

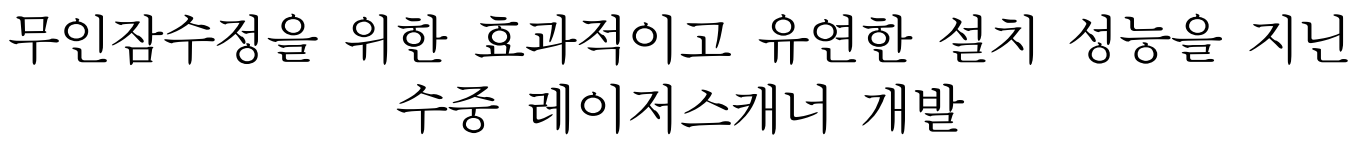

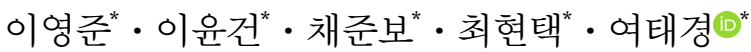 \\ *선박해양플랜트연구소 해양ICT연구본부
}

KEY WORDS: Underwater sensor 수중 센서, Laser scanner 레이저 스캐너, Vision-based 영상기반, UUV 무인잠수정, Underwater 수중

\begin{abstract}
This paper proposes a vision-based underwater laser scanner with separate structures for an underwater camera and a line laser projector. Because the two devices can be adaptively placed regardless of the features of the unmanned underwater vehicle (UUV), the scanner has significant advantages in relation to its availability and flexibility. Position calibration between the underwater camera and laser projector guarantees a 3D measuring performance with high accuracy. To verify the proposed underwater laser scanner, a test-bed system was manufactured, which consisted of the laser projector, camera, PanETilt, and Attitude and Heading Reference System (AHRS). A camera-laser calibration test and simple 3D reconstruction test were performed in a water tank and the experimental results are reported.
\end{abstract}

\section{1. 서 론}

오늘날 지상 환경에서 운용되는 장비, 계측기 그리고 로봇공 학 분야에서 언급되는 모바일 로봇 등은 많은 연구와 발전을 거듭하였고 스스로 운행이 가능한 자율 자동차의 상용화까지 바라보게 되었다. 이와 유사하게 수중 환경에서는 무인잠수정 (Unmanned underwater vehicle, UUV)이 인간의 역할을 대신하여 조사, 관측, 연구 등 다양한 목적으로 활용되고 있다. 하지만 현 실적으로 무인잠수정이 사용자에게 만족할만한 성능과 정보를 제공하고 있다고 말하기는 어렵다. 이러한 차이는 주변 환경을 인지하는 지상 센서와 수중 센서의 차이에 있다고 볼 수 있다. 예를 들어, 키넥트(Kinect, Microsoft)와 같은 3차원 계측 센서는 가격이 매우 저렴한 반면 고품질 3 차원 정보를 획득할 수 있으 며, 3 차원 라이다(Lidar)의 경우 높은 정확도를 갖는 정보의 빠 른 업데이트가 가능함에 따라 자율 자동차의 혁신적인 발전을 이끌기도 하였다. 이와 반대로, 수중 센서인 다중 음향측심기 (Multi-beam echo sounder, MBES)의 경우 센서 정보의 업데이트 속도는 초당 수회 이하로 매우 느리며 잡음이 높아 정보의 품
질이 좋지 않다. 그리고 지상에서의 엔코더(Encorder)와 같이 수 중에서 자기 속도를 알려주는 도플러 속도계(Doppler velocity $\log , \mathrm{DVL})$ 의 경우 해저면의 상태에 따라 정보 검출이 불량하여 계측 정보의 안정적인 제공이 쉽지 않다. 이러한 수중 센서의 현실적 한계로 인해 무인잠수정의 활용성은 한계에 다다르고 있고 해양 기술의 발전은 느리게 진행되고 있다.

수중 센서의 부정확한 한계를 극복하고자 수중 광학 영상을 이용한 접근이 연구되고 있다. 앞서 언급된 DVL과 같은 항법 센서에 의한 수중 위치 정확도를 높이기 위해 광학 영상이 활 용되고 있다. 선박 하부를 유영하는 수중 로봇의 위치 보정을 위해 선박 하부 광학 영상의 특징을 등록하거나(Kim and Eustice, 2013), 수중 영상에서 강인하게 나타나는 인공 표식물 (Kim et al., 2014) 또는 수중 재킷 구조의 구조적인 정보를 바탕 으로 수중 영상과 비교하여(Jung et al., 2016) 항법 성능을 높이 고자 하는 연구가 진행되고 있다. 수중에서 정밀 계측이 요구되 는 경우에 수중 광학 영상과 함께 레이저를 이용한 수중 레이 저 스캐너가 사용된다(Josep, 2004; Shukai et al., 2016). 레이저 를 점, 선, 격자 모양으로 피사체에 투영하고 영상 처리를 통해

Received 29 August 2018, revised 31 October 2018, accepted 13 December 2018

Corresponding author Tae-Kyeong Yeu: +82-42-866-3872, yeutk@kriso.re.kr ORCID: http://orcid.org/0000-0003-2742-3284

(C) 2018, The Korean Society of Ocean Engineers

This is an open access article distributed under the terms of the creative commons attribution non-commercial license (http://creativecommons.org/licenses/by-nc/3.0) which permits unrestricted non-commercial use, distribution, and reproduction in any medium, provided the original work is properly cited. 
레이저를 검출하여 물체의 정확한 외형을 계측한다. 이것은 레 이저를 사용한 능동형 시스템이기 때문에 단일 수중 카메라만 을 사용했을 때와 비교하여 탁도 및 주변 빛에 의한 간섭이 상 대적으로 적다. 이러한 원리를 이용하여 상용화된 수중 레이저 스캐너로는 ULS100/200(2G Robotics, 2016), M1500/3200(Newton labs, 2015), Subsea LiDAR(3D at Depth, 2015)가 있다. 그러나 상 용화된 장비가 존재함에도 불구하고 이를 무인잠수정에 탑재하 여 사용하기란 쉽지 않다. 레이저 스캐너는 계측 범위에 따라 카메라와 레이저 방사기 사이에 베이스라인(Baseline)이 다르다. 예를 들면, $2 \mathrm{G}$ Robotics 제품의 경우 최대 $1.0 \mathrm{~m}$ 까지 계측 가능 한 레이저 스캐너의 베이스라인은 $0.1 \mathrm{~m}$, 최대 $2.5 \mathrm{~m}$ 는 $0.3 \mathrm{~m}, 15 \mathrm{~m}$ 는 $1.2 \mathrm{~m}$ 로 늘어난다. 무인 잠수정의 경우, 레이저 스캐너가 로 봇 팔 작업과 같이 로봇의 전방 $1 \mathrm{~m}$ 내 작업 영역만을 계측하는 데 활용될 수 있는가 하면 넓은 영역에 대한 자세한 스캐닝을 필요로 할 때 활용될 수 있다. 하지만 사용 범위에 커짐에 따라 레이저 스캐너의 베이스라인이 늘어나게 되고 이는 장비의 크 기 증가로 이어진다. 결과적으로 탑재 중량 및 크기, 설치 등의 한계를 갖는 무인 잠수정에 장착하기 쉽지 않을 뿐 아니라 어 뢰형 또는 소형 무인 잠수정에는 더욱 장착이 어렵다.

이에 본 논문은 무인잠수정에 장착이 용이하고 수중 정밀 계 측이 가능한 영상 기반 수중 레이저 스캐너를 제안한다. 제안하 는 수중 레이저 스캐너는 무인잠수정에 각각 장착되는 수중 카 메라와 수중 라인 레이저를 활용하여 간단하게 시스템이 구현 되며, 카메라와 라인 레이저 사이의 보정(Calibration) 과정이 수 행된다. 이는 무인잠수정의 형태에 맞게 카메라와 라인 레이저 의 위치를 선택, 조정할 수 있어 편리하고 효과적인 장착이 가 능하게 하며, 높은 정확도와 정밀도를 갖는 3 차원 정보 획득을 보장할 수 있다. 본 논문의 2절에서는 무인잠수정에 장착이 용 이한 영상 기반 레이저 스캐너의 개념에 대해 설명하고, 3절에 서는 카메라와 라인 레이저 사이의 보정 방법에 대해 설명한다. 4절 실험에서는 영상 기반 수중 레이저 스캐너 시험 장비(Testbed)를 구성하여 카메라-레이저 보정 및 성능을 검증하여 보고, 시험 장비를 통해 획득된 수중 3 차원 정보를 이용하여 3 차원

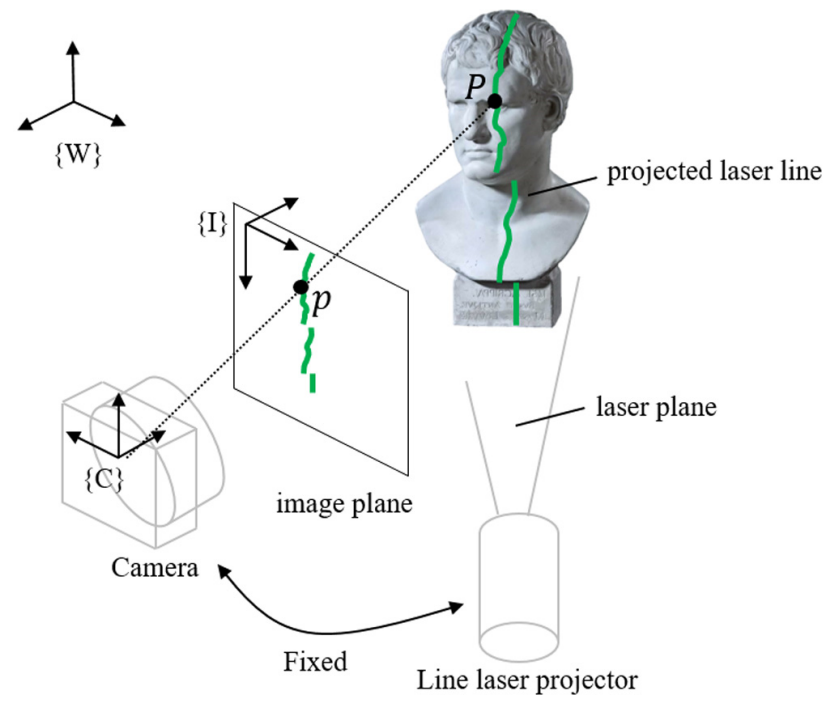

(a) Standard
복원을 수행한 결과를 소개한다.

\section{2. 영상 기반 수중 레이저 스캐너 및 무인잠수정 활용 개념}

영상 기반 레이저 스캐너는 카메라와 라인 레이저 방사기 (Line laser projector)로 구성된다. Fig. 1(a)는 이러한 시스템의 좌표계 및 거리 검출 개념을 보여준다. 레이저 방사기로부터 출 력된 녹색 라인 레이저는 전역 좌표계(World coordinate, $\{\mathrm{W}\}$ ) 상 임의의 물체 표면에 맺히게 되고 이를 카메라를 통해 획득 하여 영상 좌표계(Image coordinate, $\{\mathrm{I}\}$ ) 또는 영상 평면 상에 녹 색선으로 표현된다. 영상 처리를 통해 녹색선을 검출하면 카메 라와 라인 레이저와 위치 관계를 통해 카메라 좌표계(Camera coordinate, $\{\mathrm{C}\}$ )상 녹색선의 3 차원 위치를 검출하게 된다. 여기 서, 영상 좌표계에 맺힌 녹색선을 카메라 좌표계 상의 3 차원 위 치로 계산 할 수 있는 투영변환행렬 $\left({ }^{C} T_{I}\right)$ 이 필요하다. 이를 얻 기 위해 카메라와 라인 레이저 방사기 사이의 보정 과정이 필 요하며, 이러한 내용은 3절에서 설명한다.

수중 레이저 스캐너에 사용되는 카메라와 라인 레이저 방사 기는 크기가 소형이고 설치 위치의 큰 제약이 없기 때문에 대 형 무인잠수정뿐만 아니라 소형 무인잠수정에도 쉽게 설치 및 운영이 가능한 장점이 있다. 또한, 대부분의 무인잠수정이 전방 또는 하방 카메라를 기본적으로 장착하고 있는 것을 고려할 때 라인 레이저 방사기를 추가 설치하고, 기존 장착된 카메라와 라 인 레이저를 보정하여 운용한다면 공간 및 하중의 제약이 많은 소형 무인잠수정에는 매우 효과적인 방법이 될 수 있다. Fig. 2 는 무인잠수정의 대표적인 형태인 호버링(Hovering)형 동체와 어뢰형(Torqedo) 동체에 제안된 수중 레이저 스캐너를 장착한 예시를 보여주고 있다. 무인잠수정의 작업 영역 또는 해저면 등 의 3 차원 정보를 획득하고자 할 때 관측 영역에 맞추어 카메라 와 라인레이저 방사기를 설치하고 해당 위치에서 보정을 수행 하면 정밀한 3 차원 위치 정보를 검출할 수 있다.

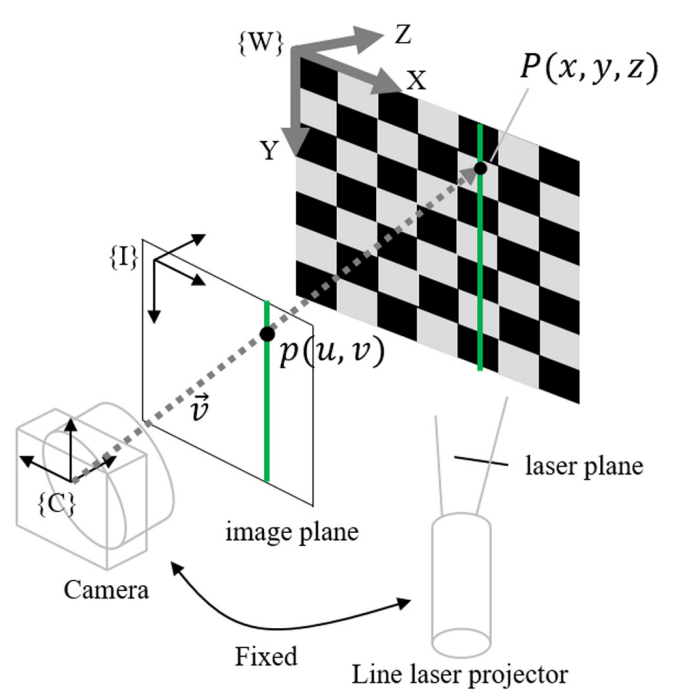

(b) Calibration

Fig. 1 Coordinate system of vision based underwater laser scanner 


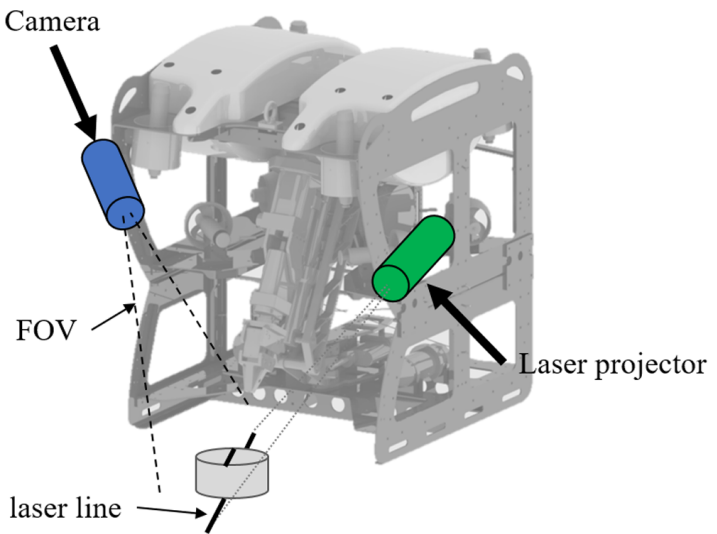

(a) Hovering type vehicle

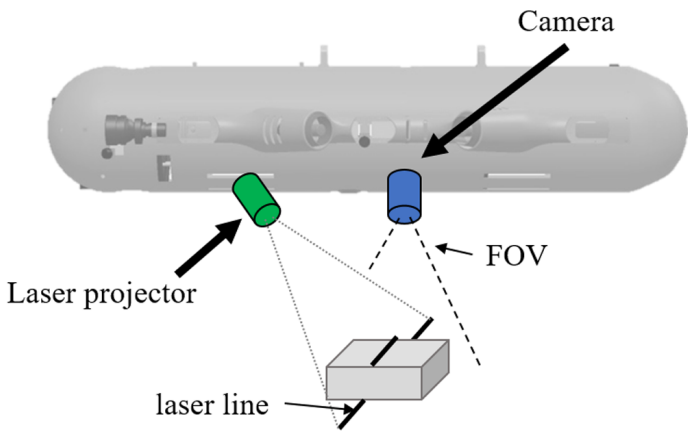

(b) Torpedo type vehicle

Fig. 2 Examples of laser scanner installation on UUV

\section{3. 카메라와 라인레이저 보정(Calibration)}

카메라와 라인 레이저 방사기의 보정 과정은 카메라 및 레이 저 방사기의 무인잠수정 장착의 용이성 및 레이저 스캐너의 계 측 정확도를 높이는데 있어 매우 중요한 과정이다. 앞서 언급하 였듯이 보정 과정을 통해 영상 좌표계 또는 영상 평면에 맺힌 녹색 라인의 픽셀 위치 $\left([u, v]^{T}\right)$ 를 카메라 좌표계 상의 3 차원 위 치 $\left([x, y, z]^{T}\right)$ 로 계산 할 수 있는 변환행렬 $\left({ }^{C} T_{I}\right)$ 을 얻고자 한다. 이를 위해 Fig. 1(b)와 같이 체스보드를 이용하고자 한다.

보정은 체스보드 평면과 레이저 직선(Laser ray, $\vec{v})$ 을 활용하여 평면과 직선이 교차하는 3 차원 점 $P(x, y, z)$ 의 위치를 유도하는 방 법으로 수행된다. 이를 위해 첫 번째, 카메라 좌표계 상에 정의된 체스보드 평면을 구하기 위해 전역 좌표계와 카메라 좌표계 사이 의 회전 변환 행렬 $(M)$ 을 구한다. 두 번째, 회전 변환 행렬(있는가하 면)을 통해 체스보드 평면의 방정식을 유도한다. 세 번째, 영상 평 면에 나타난 녹색선 위의 점 $p(u, v)$ 를 이용하여 $\vec{v}$ 를 유도하고 체스 보드 평면과 벡터 $\vec{v}$ 의 교차점 $P(x, y, z)$ 를 구한다. 이때 녹색선 위의 점 $p(u, v)$ 는 녹색선의 세로축 방향 길이에 따라 다수가 될 수 있다. 마지막으로 영상 위의 점 $p_{i}(u, v)[i=1,2, \cdots, n]$ 과 이에 대응하는 3 차원 상의 점 $P_{i}(x, y, z)[i=1,2, \cdots, n]$ 을 바탕으로 영상 좌표계에서 3 차원 좌표계로 투영되는 변환행렬 $\left({ }^{C} T_{I}\right)$ 을 계산한다.

\section{1 전역 좌표계와 카메라 좌표계 사이의 변환 행렬 $M$}

카메라를 기준으로 상대적인 거리를 검출하기 때문에 최종적 으로 얻고자 하는 3 차원 상의 위치는 카메라 좌표계에서 표현 된다. 카메라 좌표계 상에서의 체스보드 평면의 방정식을 구하 기 위해 투영 변환을 이용한다. Fig. 1(b)와 같이 전역 좌표계 $(\{\mathrm{W}\})$ 가 체스보드 평면에 존재 할 때 체스보드의 정사각형 패 턴의 크기를 이미 알고 있으므로 $z_{W}=0$ 으로 하는 패턴 교차점 의 3 차원 위치를 정의할 수 있다. 또한, 체스보드 패턴 교차점 의 영상 내 위치 $p(u, v)$ 는 영상 처리를 통해 얻을 수 있다. 이러 한 두 정보를 이용하여 식 (1)의 투영행렬 $(K)$ 을 정의할 수 있고 식 (2)와 같이 선형 방정식 형태로 변환하여 다수의 대응점에 만족하는 투영행렬을 얻을 수 있다. 사전에 핀홀 카메라 보정을 통해 카메라 내부 파라미터 $(A)$ 를 알고 있다고 가정하면 전역
좌표계와 카메라 좌표계 사이의 변환 행렬 $(M)$ 을 얻을 수 있다.

$$
\begin{aligned}
& {\left[\begin{array}{l}
u \\
v \\
1
\end{array}\right]_{I}=K\left[\begin{array}{l}
x \\
y \\
z \\
1
\end{array}\right]_{W}=\left[\begin{array}{llll}
k_{11} & k_{12} & k_{13} & k_{14} \\
k_{21} & k_{22} & k_{23} & k_{24} \\
k_{31} & k_{32} & k_{33} & 1
\end{array}\right]\left[\begin{array}{l}
x \\
y \\
z \\
1
\end{array}\right]_{W}=s A M\left[\begin{array}{l}
x \\
y \\
z \\
1
\end{array}\right]_{W}}
\end{aligned}
$$

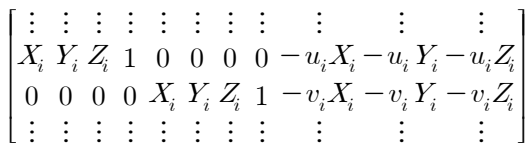

$$
\begin{aligned}
& {\left[k_{11} k_{12} k_{13} k_{14} k_{21} k_{22} k_{23} k_{24} k_{31} k_{32} k_{33}\right]^{T}=\left[\begin{array}{c}
\vdots \\
u_{i} \\
v_{i} \\
\vdots
\end{array}\right]}
\end{aligned}
$$

\section{2 체스보드 평면 방정식}

카메라 좌표계를 기준으로 체스보드 평면 방정식을 유도한다. 평면 방정식은 원점을 지나는 법선벡터와 평면 사이의 교차점 으로 표현된다. 카메라 좌표계 상의 체스보드 평면의 법선 벡터 와 교차점은 전역 좌표계 상의 체스보드 법선벡터와 교차점을 변환행렬 $(M)$ 에 의해 식 (3)과 식 (4)와 같이 계산된다. 전역 좌 표계 상의 원점을 지나는 법선벡터는 $n_{W}=[0,0,1]^{T}$ 이고, 교차점 은 $p_{W}=[0,0,0]^{T}$ 이다. 그리고 평면 방정식에 의해 $d_{C}=n_{C}^{T} \cdot p_{C}$ 를 얻을 수 있다.

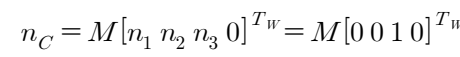

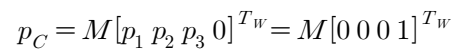

이를 통해 카메라 좌표계에서 본 체스보드 평면의 방정식은 식 (5)와 같다.

$$
n_{W}^{T} \cdot P=d_{C}
$$

\section{3 체스보드 평면과 $\vec{v}$ 의 교차점 $P(x, y, z)$}

Fig. 1(b)에서 $\vec{v}$ 는 카메라의 원점, 영상 평면에 나타난 녹색선 
에 해당하는 픽셀 $p(u, v)$, 그리고 교차점 $P(x, y, z)$ 를 지난다. 식 (6)은 이러한 $\vec{v}$ 를 이용하여 점 $P(x, y, z)$ 의 위치를 보여준다. 여기 서 $O_{C}$ 는 카메라 좌표계의 원점을 나타내며, 직선의 방향을 나타 내는 $\vec{v}$ 는 카메라 원점과 $p(u, v)$ 값을 이용하여 얻을 수 있다.

$$
P=\lambda \vec{v}+O_{C}
$$

그리고 체스보드 평면 방정식인 식 (5)를 이용하여 식 (7)과 같이 $\lambda$ 를 계산하여 최종적으로 점 $P(x, y, z)$ 의 위치를 얻을 수 있다.

$$
\left\{\begin{array}{l}
n_{C}^{T} \cdot P=d_{C} \\
P=\lambda \vec{v}+O_{C}
\end{array} \Rightarrow \lambda=\frac{d_{C-} n_{C}^{T} \cdot O_{C}}{n_{C}^{T} \cdot \vec{v}}\right.
$$

\section{4 투영 변환 행렬 ${ }^{C} T_{I}$}

우리가 최종적으로 얻고자 하는 것은 영상 평면에 나타난 녹 색 라인 레이저의 픽셀 위치를 3 차원 카메라 좌표계로 변환하 는 행렬을 얻는 것이다. 앞서 과정을 통해 영상 평면의 위의 점 $p(u, v)$ 를 카메라 좌표계 상의 3차원 점 $P(x, y, z)$ 으로 변환하는 과정을 유도하였다. 이를 이용하여 Fig. 1(b)에 영상 평면 위의 모든 녹색 점에 대응하는 카메라 좌표계 상의 점을 계산하여 식 (8)과 같은 관계식을 이용하여 투영 변환 행렬 $\left({ }^{C} T_{I}\right)$ 을 얻을 수 있다.

$$
\left[\begin{array}{l}
x \\
y \\
z \\
1
\end{array}\right]_{C}={ }^{C} T_{I}\left[\begin{array}{l}
u \\
v \\
1
\end{array}\right]_{I}=\left[\begin{array}{l}
t_{11} t_{12} t_{13} \\
t_{21} t_{22} t_{23} \\
t_{31} t_{32} t_{33} \\
t_{41} t_{42}
\end{array}\right]\left[\begin{array}{c}
u \\
v \\
1
\end{array}\right]_{I}
$$

\section{4. 성능 실험 및 결과 분석}

제안된 무인잠수정에 장착이 용이한 영상 기반 레이저 스캐 너의 성능 검증을 위해 실험을 수행한다. 2절에서 언급하였듯이 카메라와 라인 레이저 방사기는 무인잠수정의 형태 및 편의에 따라 임의의 위치에 설치하여도 된다. 본 실험에서는 제안된 방 법의 성능 검증을 위해 Fig. 3(a)에서 보는 것과 같이 금속 프로 파일 위에 카메라와 레이저 방사기를 단단히 고정하여 카메라레이저 보정을 수행하고 성능을 검증한다. 그리고 좌우 스캐닝 을 위한 자세 제어 구동기(Pose actuator)와 자세 센서(Pose sensor)를 추가 장착하여 Fig. 3(b)에서의 시험수조에서 Fig. 3(c) 와 같이 물체와 레이저 스캐너를 수중에 설치 후 수중 물체에 대한 3차원 복원을 수행하여 본다. 해당 시험 장비의 전체 사양 은 Table 1 과 같다.

\section{1. 카메라와 라인레이저 보정 및 성능 분석}

카메라와 라인레이저의 보정을 위해 Fig. 4와 같이 두 장의 체스보드 영상을 획득하였다. 체스보드는 가로 8 개, 세로 8 개의 교차점을 가지며 정사각형의 크기는 $40 \mathrm{~mm}$ 이다. 카메라로부터 거리는 약 $0.6 \mathrm{~m}$ (Near)와 약 $1.4 \mathrm{~m}$ (Far)이다. Fig. 4(a)는 OpenCV 함수를 활용하여 체스보드 교차점을 검출한 결과이다 $(\mathrm{OpenCV}$, 2018). 이를 통해 얻어진 체스보드의 3차원 위치는 Fig. 5(a)와 같으며, Fig. 5(b)는 얻어진 체스보드의 3차원 위치를 영상 평면 으로 재투영(Reprojection)하여 오차를 확인한 결과이다. 식 (9) 는 얻어진 체스보드 평면 방정식이다.

$$
\left\{\begin{array}{l}
\neq \text { ar }: \quad 0.0220375 x-0.013276 y+0.999669 z=641.048 \\
\text { Far }: \quad-0.00310779 x-85.0732 y+0.999933 z=1364.26
\end{array}\right.
$$

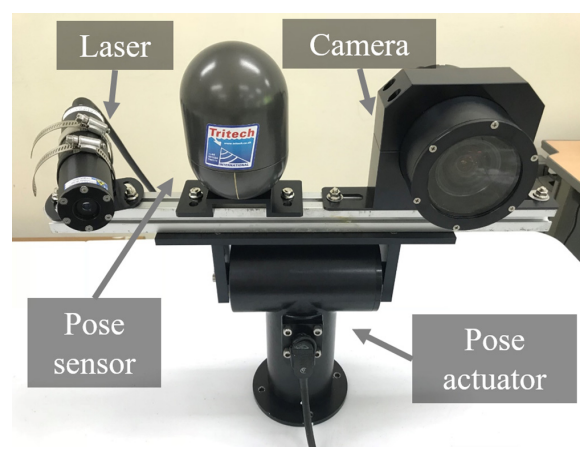

(a) Underwater laser scanner test-bed

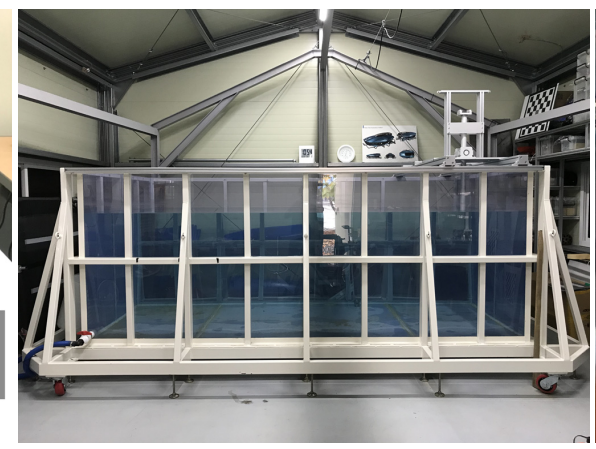

(b) Trimming tank (KRISO)

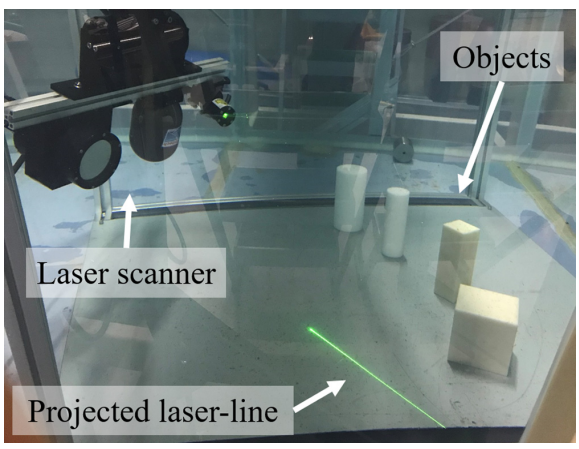

(c) Experimental set-up

Fig. 3 Vision based underwater laser scanner system

Table 1 Specification of vision based laser scanner test-bed

\begin{tabular}{ccccc}
\hline \hline Device & Name & Model & Specification & Purpose \\
\hline Camera & FLIR blackfly & BFLY-PGE-23S6C-C & 41 FPS at $1920 \times 1080$ & Image acquisition \\
Line laser & Global laser & GreenLyte-MV-EXCEL & $532 \mathrm{~nm}, 75^{\circ}$ & Laser projector \\
Sensor & Tritech & Intelligent gyro compass & res. $<0.1 \%$ acc. $<1^{\circ}$ & Pose sensor \\
Actuator & SIDUS pan / tilt & SS109 & Torque. 13.6 Nm & Actuator \\
\hline
\end{tabular}




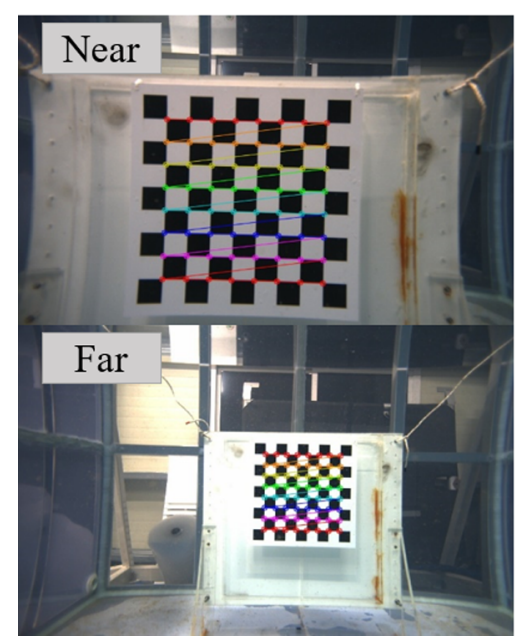

(a) Detected chessboard

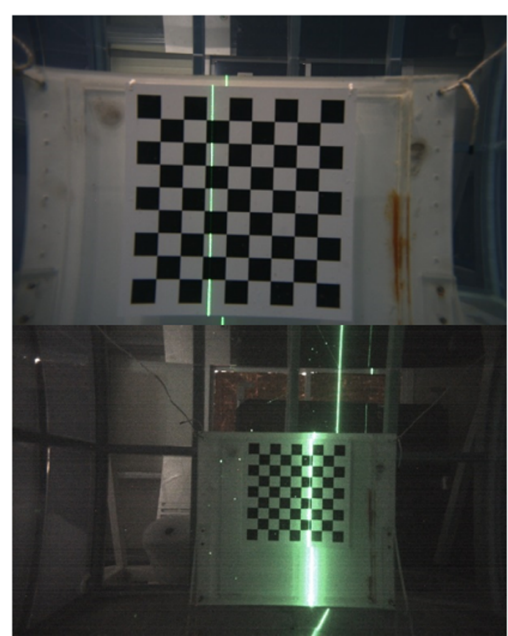

(b) Line laser

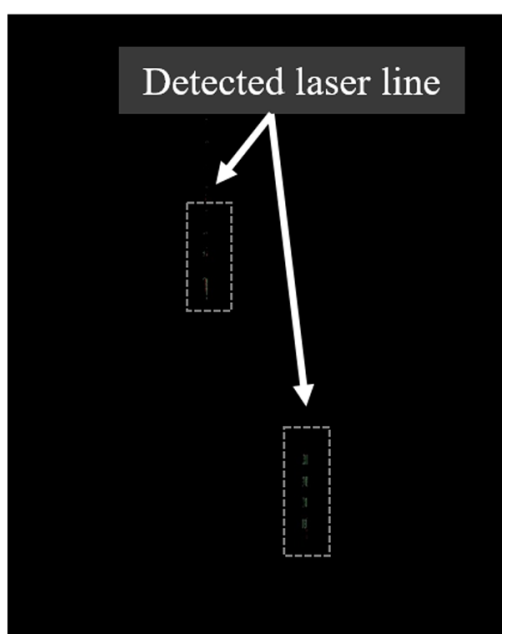

(c) Detected laser line (after processing)

Fig. 4 Experiment of camera-laser calibration in water-tank

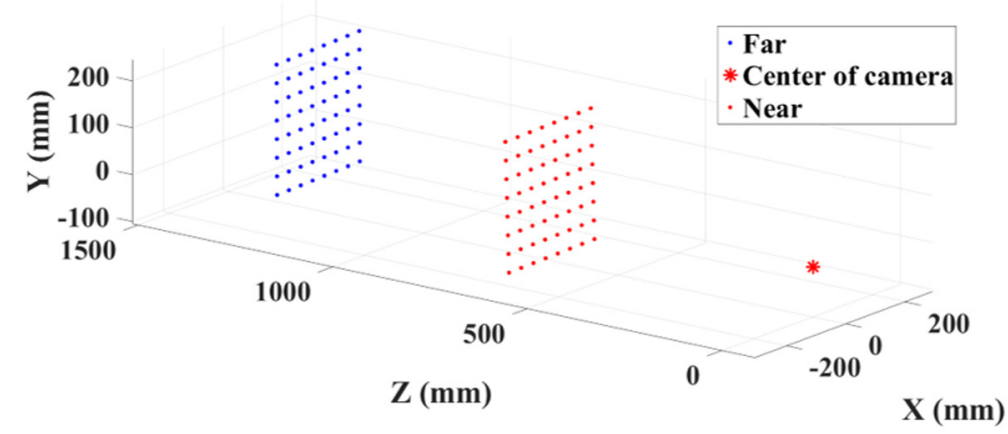

(a) Estimated 3D position of chessboard corner

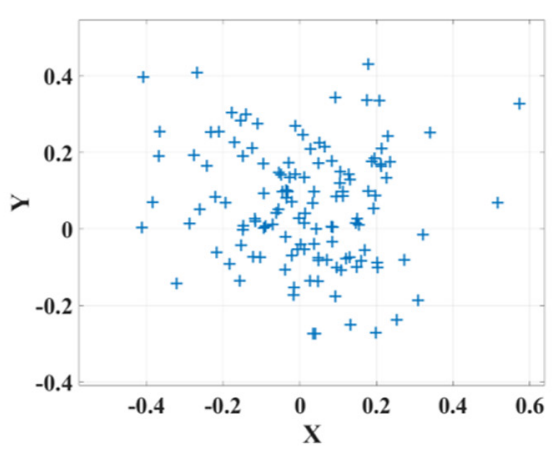

(b) Reprojection error (in pixel)

Fig. 5 Analysis of projection matrix $K$ and $M$

Fig. 4(b)와 같이 체스보드 평면에 투영된 녹색 라인 레이저를 검출한 결과는 Fig. 4(c)와 같다. 검출된 점의 개수는 총 34 개이 며, 식 (6)과 식 (7)을 이용하여 각 점에 대응하는 카메라 좌표 계 상의 3 차원 위치를 추정하였다. 그리고 영상 평면 위의 점과 추정된 카메라 좌표계 위의 3 차원 점 사이의 투영 변환 행렬 ${ }^{C} T_{I}$ 는 식 (10)과 같다.

$$
{ }^{C} T_{I}=\left[\begin{array}{ccc}
0.462771 & -0.001867 & -224.44278 \\
0.0024317 & 0.469019 & -138.8021 \\
0.0195404 & 0.045971 & 301.25772 \\
-0.001350 & 0.0000680 & 1
\end{array}\right]
$$

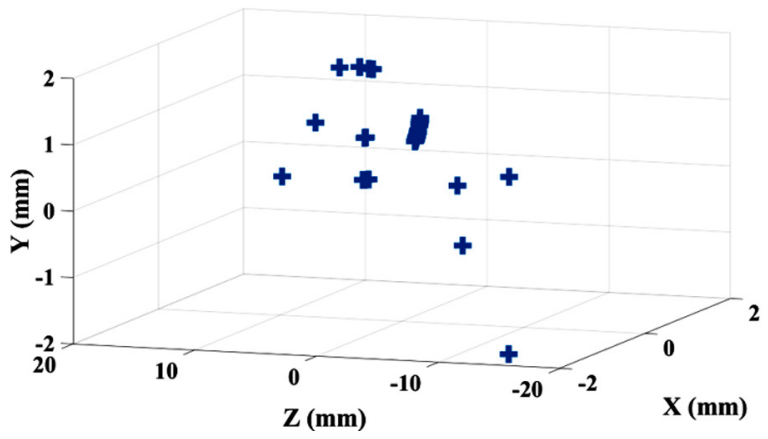

(a) Laser plane

Fig. 6 3D reprojection error of laser scanner test-bed
얻어진 투영 변환 행렬을 검증하기 위해 두 가지 방법의 재투 영 오차를 분석하였다. 첫 번째 방법은 레이저 평면에 재투영하 는 방법이다. 얻어진 3차원 위치 점을 이용하여 레이저 평면을 검출한 후 3.3 절에서 언급하였던 것과 같이 레이저 직선 $\vec{v}$ 와 레 이저 평면의 교차점을 계산하여 3 차원 위치를 계산하여 오차를 비교한다. 두 번째 방법은 일반적인 재투영 방법과 같이 ${ }^{C} T_{I}$ 를 이용하여 3차원 위치를 계산한다. Fig. 6은 이러한 방법을 이용 한 재투영 오차 결과이다. 전체적인 오차 범위는 $X$ 축 $< \pm 4 \mathrm{~mm}$, $\mathrm{Y}$ 축 $< \pm 2 \mathrm{~mm}, \mathrm{Z}$ 축 $< \pm 20 \mathrm{~mm}$ 이내에 존재한다. $\mathrm{X}$ 축과 $\mathrm{Y}$ 축은 매 우 작은 오차를 갖으나 $\mathrm{Z}$ 축은 총 추정된 위치 중 약 $20 \%$ 이하에

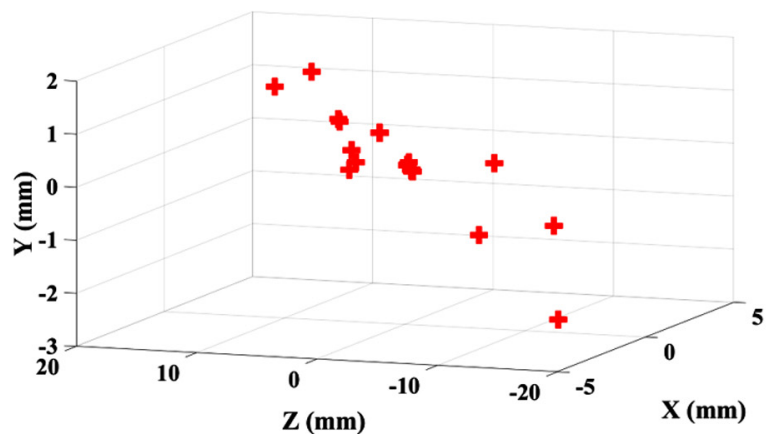

(b) Projection matrix ${ }^{C} T_{I}$ 
서 상대적으로 큰 오차를 갖는다. 이러한 이유는 $\mathrm{Z}$ 축 방향에 대 한 보정을 위해 다양한 정보가 주어지지 않았기 때문이다. 이에 다양한 거리의 체스보드 영상을 획득할 필요가 있다. 레이저 평 면 재투영 오차의 평균오차는 $5.08 \mathrm{~mm}\left(\sigma^{2}=3.78 \mathrm{~mm}\right)$ 이고, 투영 변 환 행렬 $\left({ }^{C} T_{I}\right)$ 에 의한 재투영 오차의 평균오차는 $2.87 \mathrm{~mm}\left(\sigma^{2}\right.$ $=4.35 \mathrm{~mm})$ 을 나타났다.

\section{2. 수중 3 차원 복원}

보정이 완료된 레이저 스캐너를 이용하여 Fig.3-(b)와 같은 수 중 환경에 대한 복원을 수행하였다. 복원 실험은 영상 기반 수 중 레이저스캐너가 실제 복원을 위해 적합한가에 대한 검증을 위해 수행되었다. 자세 구동기를 이용하여 스캐닝을 하고 자세 센서를 통해 자세 정보를 얻는다.

Fig. 7은 3차원 복원된 결과를 보여준다. 총 4개의 물체가 놓여있고, 왼쪽부터 원형기둥 1 , 원형기둥 2 , 사각기둥, 정육면 체이다. Table 2 는 개별 물체의 실제 크기와 레이저 스캐너에 의해 측정된 크기를 보여준다. 실제 크기와 측정된 크기의 오 차를 보면 전체 물체에서 수 밀리미터 오차를 갖는다. 제안된 방법의 레이저 스캐너의 적용 분야에 따라 요구되는 측정 성 능이 다를 수 있으나 3 차원 물체에 대한 인식을 고려하였을 때 상기 오차는 물체 인식에 큰 영향을 주지 않는다. 전체적인 물체의 외형을 보면 실제 물체와 근접하게 복원된 것을 볼 수 있다. 또한, 원형기둥의 원모양과 사각기둥의 전방 좌/우면이 실제 물체와 매우 근접하다. 복원된 바닥면 및 물체 상단의 평 탄도가 매우 균일하게 복원되었음을 확인할 수 있다. 이는 공 간 분할 시 평면 검출 또는 평면 제거에 매우 유리한 결과를 얻을 수 있다.

\section{5. 결 론}

본 연구는 수중 정밀 계측이 가능하고 다양한 무인잠수정의 용 도 및 형태에 맞게 조정 및 운용이 가능한 영상 기반 수중 레이저 스캐너를 제안함으로서 고품질 수중 3 차원 정보 획득 및 무인잠수 정의 현실적인 활용도를 높이고자 함을 그 목표로 한다. 이에 본 논문은 별도로 구성된 수중 카메라와 수중 라인 레이저 방사기를 무인잠수정의 용도 및 형태에 맞게 설치하여도 카메라-레이저 보 정을 통해 정확한 3 차원 정보를 획득할 수 있음을 검증 실험을 통해 분석하였다. 그리고 수중 레이저 스캐너의 적용 분야인 3 차원 복원을 수행해 봄으로서 그 효용성을 확인하였다.

능동형 시스템인 수중 레이저는 수중 음향에 편중된 수중 센 서의 한계를 극복하고 빛, 탁도에 의해 영향을 많이 받는 수중 광학 영상의 문제점을 극복할 수 있는 대안이 될 수 있다. 다만, 실질적인 해양 환경에서 강인한 계측 성능을 확보할 수 있는지 에 대한 성능 검증을 계속해서 연구 개발 되어야 한다. 수중 레 이저를 이용하여 안정적이고 정확한 정보 획득 및 소형화가 가 능하여 무인잠수정 설치가 용이하며 이는 수중 활용에 매우 효 과적인 장점을 갖는다. 이에 본 연구에서 개발된 수중 레이저 스캐너는 보유하고 있는 소형 무인잠수정에 탑재하여 수중 물 체 복원 및 인식 등의 다양한 연구 분야에 적용할 계획이다.

\section{후기}

본 연구는 선박해양플랜트연구소의 주요사업인 ‘수중 자율작 업을 위한 3 차원 물체인식 및 로봇-로봇 팔 운동보상제어 기반 기술 개발'에 의해 수행 되었습니다(PES9400).

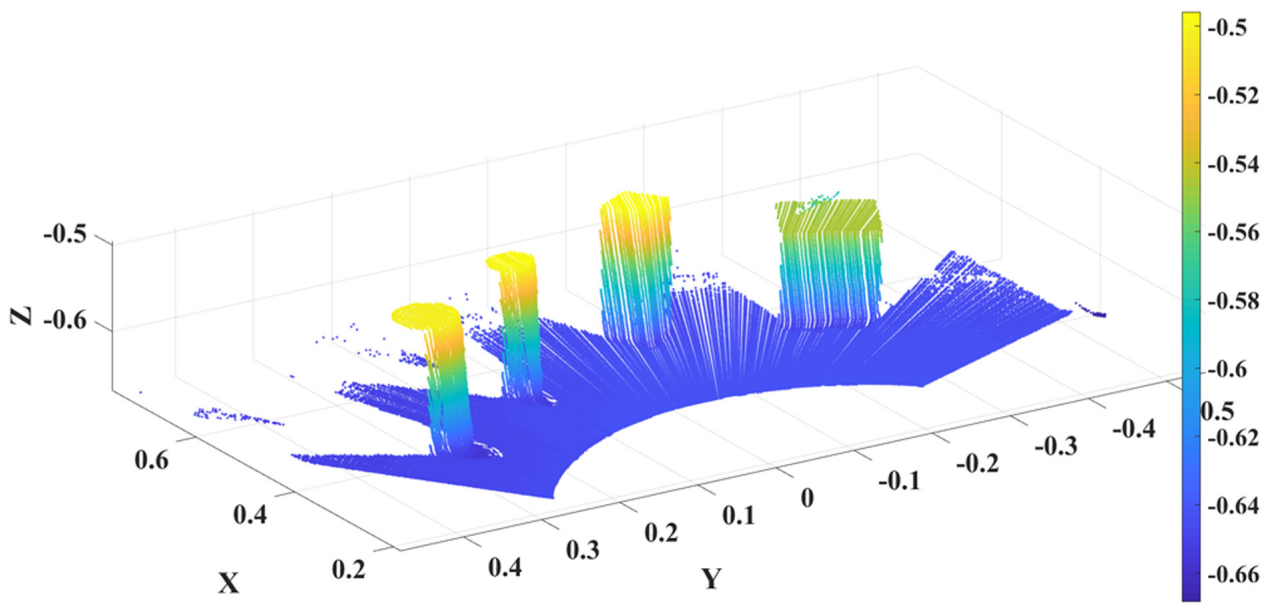

Fig. 7 Reconstruction result by laser scanning experiment (in meter)

Table 2 Real and measured dimensions of 4 objects

* H: height, D: depth, W: width

\begin{tabular}{ccc}
\hline \hline Object & Real dimensions & Measured dimensions \\
\hline Cylinder 1 & $\phi 75 \mathrm{~mm}, 150 \mathrm{~mm}(\mathrm{H})$ & $\phi 72.5 \mathrm{~mm}, 145 \mathrm{~mm}(\mathrm{H})$ \\
Cylinder 2 & $\phi 50 \mathrm{~mm}, 150 \mathrm{~mm}(\mathrm{H})$ & $\phi 49.6 \mathrm{~mm}, 149 \mathrm{~mm}(\mathrm{H})$ \\
Square pillar & $50 \mathrm{~mm}(\mathrm{~W}, \mathrm{D}), 150 \mathrm{~mm}(\mathrm{H})$ & $51.1 \mathrm{~mm}(\mathrm{~W}) 49.1 \mathrm{~mm}(\mathrm{D}) 150 \mathrm{~mm}(\mathrm{H})$ \\
Cube & $100 \mathrm{~mm}(\mathrm{~W}, \mathrm{D}, \mathrm{H})$ & $96.9 \mathrm{~mm}(\mathrm{~W}) 101.2 \mathrm{~mm}(\mathrm{D}) 96 \mathrm{~mm}(\mathrm{H})$ \\
\hline
\end{tabular}




\section{References}

2G Robotics, 2016. ULS-100 Manual. [Online] Available at : $<$ http://www.2grobotics.com/products/underwater-laser-scann er-uls-100/> [Accessed 26 August 2018].

3D at Depth, 2015. SL1/SL2/SL3 Product Sheet. [Online] Available at : <https://www.3datdepth.com/> [Accessed 26 August 2018].

Josep, F.C., 2004. New Methods for Triangulation-based Shape Acquisition using Laser Scanners. Ph.D. Thesis, Univesity of Girona, 150.

Jung, J., Li, J.H., Choi, H.T., Myung, H., 2016. Localization of AUVs Using Visual Information of Underwater Structures and Artificial Landmarks. Journal of Intelligent Service Robotics, 10(1), 67-76

Kim, A., Eustice, R.M., 2013. Real-time Visual SLAM for
Autonomous Underwater Hull Inspection Using Visual Saliency. IEEE Transactions on Robotics, 29(3), 719-733.

Kim, D., Lee, D., Myung, H., Choi, H.T., 2014. Artificial Landmark-based Underwater Localization for AUVs Using Weighted Template Matching. Journal of Intelligent Service Robotics, 7(3), 175-184.

Newton Labs, 2015. Underwater Laser Scanners Manual. [Online] Available at : <http://www.newtonlabs.com/ subsea_scanners-1. htm $>$ [Accessed 26 August 2018].

OpenCV, 2018. The OpenCV Library. [Online] Available at : $<$ https://opencv.org/> [Accessed 26 August 2018].

Shukai, C., Zexiao, X., Wenzhu, C., 2016. A Laser Line AutoScanning System for Underwater 3D Reconstruction. Journal of Sensors (MDPI), 16(9), 1534. 